\title{
Entrepreneurial Values, Cognitive Attitude toward Business and Business Behavioural Intention of ABM Grade 12 and Fourth-Year Business Management Students: A Comparative Study
}

\author{
Damianus Abun ${ }^{1}$, Theogenia Magallanes ${ }^{2}$, Frelyn, B. Ranay ${ }^{1}$, Nimfa C. Catbagan ${ }^{3} \&$ Rodelyn, J. Calairo ${ }^{4}$ \\ ${ }^{1}$ School of Business, Divine Word College of Laoag, Ilocos Norte, Philippines \\ ${ }^{2}$ School of Religious Education, Saint Benedict College of Northern Luzon, Ilocos Sur, Philippines \\ ${ }^{3}$ School of Arts, Science, and Education, Divine Word College of Laoag, Ilocos Norte, Philippines \\ ${ }^{4}$ School of Basic Education, Divine Word College of Laoag, Ilocos Norte, Philippines \\ Correspondence: Damianus Abun, School of Business, Divine Word College of Laoag, Ilocos Norte, Philippines.
}

Received: November 16, 2021; Accepted: December 1, 2021; Published: December 3, 2021

The Research is funded by Divine Word College of Laoag, Laoag City, Ilocos Norte, Philippines.

\begin{abstract}
The study aimed to determine the difference in entrepreneurial values, cognitive attitude toward business, the business intention between ABM grade XII and the fourth-year college students of business management course. It also seeks to find out the effect of entrepreneurial values, cognitive attitude toward the business behavioral intention. The study found that entrepreneurial values, cognitive attitude toward business, and business intention of students are high and it further found that there is no significant difference between entrepreneurial values, cognitive attitude toward business, the business intention of ABM grade XII students, and the fourth - year college students of business management course. Thus, the hypothesis is rejected. It also found that there is a significant correlation between entrepreneurial values, cognitive attitude toward the business, and business behavioral intention. Therefore, the hypothesis is accepted.
\end{abstract}

Keywords: attitude, entrepreneurial values, business intention, values education

\section{Introduction}

Covid-19 has practically knocked down all business establishments around the globe. There is no country exempted from the economic damage caused by Covid-19. Countries that are known to be strong economically like the USA, China, and Japan are all affected and pushed their economic growth to a lower level and even to a minus level in the first and second quarter in 2020. There are even fears that economic recovery would be slower in the coming years and it would continue experiencing contraction across the vast majority of emerging markets and developing economies (The World Bank, 2020). Bringing back the economy to where it was before the pandemic time would take time, if not take a decade to restore to bring it back. Consequently, unemployment is increasing making it hard for people to pay their bills, their rents, and other basic needs.

Relying one hundred percent on the government to restore the economy without the participation of its citizens would be hard to restore the economy. On the government side, it needs to improve its governance and business environment to attract more investors and increase spending in education and public health. While on people's side, they need to see new business opportunities to invest and create a business. The question is: do they see the opportunity as a result of Covid-19 and are they ready to go into business? Going into business is not only a matter of capital but it is also a matter of one's cognitive attitude toward business and a matter of entrepreneurial values. Knowledge (cognitive attitude toward business), capital, and entrepreneurial values are considered necessary to start and to run a business. The World Bank in its press release on June 2, 2020, pointed out that to make the economy more resilient, the countries must build and strengthen their human capital (The World Bank, 2020, Baah-Boateng, 2013). Human capital with knowledge and values.

Building human capital is to improve and strengthen the education sector where human capital is trained (Crocker, 2006). The human capital theory argues that society is functioning not just because of its financial capital, labor, and natural resources but it is also a function of the knowledge and skills of its members (Crocker, 2006). This is 
a particular challenge of business education courses and also other courses. As pointed out by Bets (2010) that the challenge for schools is to provide talented, competent, and knowledgeable teachers to impart the same to the students. A particular challenge for a business education course is to prepare students to become an entrepreneur. The role of a Business education course is to provide students with enough knowledge and skills about a business and how to run a business. This knowledge and skills must be learned in the school since this is the purpose of business education courses. Students need to be equipped with the necessary business knowledge and skills to go into business.

However, going into business is not a matter of financial capital and knowledge but is also a matter of values. Though there are many pieces of research pointed out that entrepreneurial knowledge is a predictor of business intention (Abun, et.al. 2018, Malebana, 2014, Kadir, et.al. 2012), however, other studies also provide us an idea that entrepreneurial knowledge does not necessarily motivate students to go into business in the future. For example, the study of Holwerda (2018) found out that students who have financial knowledge do not have the intention to go into business in the future compared to students who possess the value of creativity and self-efficacy. This finding is similar to the finding of Koe, et.al. (2018) that creativity and innovation are correlated to business intention but not knowledge. In this case, it is not just a matter of knowledge but also attitude and behavior (Kadir, et. al, 2012). Thus, based on these findings, business education must not only provide current knowledge to students but motivate and awaken the entrepreneurial values of the students. Students may know but they do not have entrepreneurial values. The challenge here is: how can the colleges or universities awaken entrepreneurial mindset? It is still debatable if the entrepreneurial mindset can be taught by the teacher in the classroom. Abun (2018, cited from Sarasvathy, 2015) argued that an entrepreneurial mindset can be taught only by the entrepreneurs themselves, and thus it is recommended to bring entrepreneurs inside the classroom.

The current study intends to find out if students who have taken up an entrepreneurship course and have learned the necessary skills in doing business have ideas about business and have the plan to go into business. It is also to find out if students who have learned entrepreneurship have developed entrepreneurial values and will plan to go into business. There have been studies related to the correlation between entrepreneurial knowledge and entrepreneurial intention as we have mentioned above but there have been no studies related to entrepreneurial values, cognitive attitude toward business, and business intention. This is the first study to find out the difference between the entrepreneurial values, cognitive attitude toward business, and business intention of grade XII and fourth-year students who have taken entrepreneurship courses. This current study pursues such a gap and besides, it also provides ideas on how to awaken the entrepreneurial values of the students.

The study is divided into five parts. The first part is the introduction which explains the rationale of the study. The second part is the related literature review that presents the existing literature that explains the theory of the current study. The Third part is the research methodology that discusses the research design, population, locale of the study, research instruments, data gathering procedures, and statistical treatment of data. The Fourth part is empirical data and analysis in which the data are presented, interpreted, and analyzed. The Fifth part is the result and discussion. This is to discuss further the result of the study.

\section{Related Literature}

A review of related literature is an important step in conducting a scientific study. It provides the foundation of knowledge and theories of the current study. Beyond that, it provides information for the current study about what other researchers have discovered related to the topic, and by knowing what others have done related to the topics, then duplication can be avoided. Related to this concept, this part of the study would present theories of the study supported by the existing knowledge of previous researchers (UPSTATE University of South Carolina, n.d).

\subsection{Entrepreneurial Values and Entrepreneurship}

Before we discuss entrepreneurial values and entrepreneurship, we need to understand who an entrepreneur is because values are not existing or operate independently of a human person. Values are possessed by an entrepreneur which guides the behavior of an entrepreneur. Merriam - Webster Dictionary defines an entrepreneur as "the one who organizes, manages, and assumes the risk of a business or enterprise". This definition refers to a person who is taking the risk to start and manage a business. This is similar to the definition of Investopedia (n.d) as it defines an entrepreneur as "an individual who creates a new business, bearing most of the risk and enjoying most of the reward". These definitions single out the important characteristics of an entrepreneur such as "innovator, the originator of new ideas, and new ways of doing things", (Investopedia, n.d). This concept is related to the definition of an entrepreneur in the Cambridge Dictionary as it sees an entrepreneur as "someone who starts his/her own business, especially when this involves seeing a new opportunity". The concept of an entrepreneur as provided by the dictionaries are similar to the definition offered by Schumpeter (1965) that an entrepreneur is are "individual 
who exploit market opportunity through technical and/or organizational innovation". Bolton and Thompson (2000) also offered a similar definition of an entrepreneur as "a person who habitually creates and innovates to build something of recognized value around perceived opportunities". From all these definitions, the entrepreneur is referring to the values or mindset of a person. In this regard, entrepreneurs are defined by their values such as risktaking, adventure, innovativeness, exploiter of opportunity, and challenger of the status quo.

Entrepreneurs and values are not two different entities but they are one because values are the values of an entrepreneur. Values are what someone considers most important to him/her and they become the source of motivation ((Mankoff, 1974) and the guide for decision making (Brown \& Assoiates, 2002). Values predict the behavior of a person ((Meglino, Ravlin, \& Adkins, 1989, Rokeach, 1973), it is the guide of a person on how to behave and determines what are the important things for him (Feather, 1994, p. 35). As pointed out by Bolton and Thompson (2000), an entrepreneur is a person who creates something new or innovates an existing product that has not been thought of by others based on a recognized value and opportunity to make a business. He is the one who takes the risk and translates a business opportunity into a business (Knight (1921) and Drucker (1970). This concept provides an idea that an entrepreneur is defined by the values he/she possesses because values are reflected in his/her behavior (Halis, et.al. 2007, Malovics, et.al. 2015). Thus, an entrepreneur is not a value-free person but a value-driven person (Smilor, 2004). Thus entrepreneurial values mean the values that are held by entrepreneurs (Morris \& Schindehutte, 2005). According to Schwartz (2011), the behavior of an entrepreneur is motivated by his/her values. Concerning the origin of these values, it is argued that values are the product of culture (Hofstede, 1984) and therefore, there can be different entrepreneurial values in different places held by the entrepreneurs (Eroglu \& Picak, 2011). Though it may be true that values are the product of culture and therefore values may not be universal, however, McGrath (1992) held that there are also shared values held by different entrepreneurs across the border.

Entrepreneurs and entrepreneurship are two terms that cannot be separated because one is referring to a person who initiates entrepreneurship or business (Investopedia, n.d, Bolton and Thompson (2000), but both have a different meaning. Entrepreneurship is a process of establishing a business that is emanated from business opportunities or market demand (Schumpeter, 1965). It is a business activity that an entrepreneur initiates or originates to create a customer and profits (Drucker, 1970). While Stevenson as cited by Haizkoeta (2020) entrepreneurship is "the pursuit of business opportunity beyond resources controlled". From these definitions, one can understand that one is not called an entrepreneur if he/she is not able to translate his/her ideas into business activities or entrepreneurship.

As we have pointed out above that entrepreneurs are values-driven individuals. Though these values are culturally driven or formed by the culture and therefore there can be differences in terms of values possessed by entrepreneurs depending on the culture where they are raised, however, it is also true that there are shared values held by entrepreneurs across the border (McGrath (1992). Ronconi and Anchorena (2012) identified independence (autonomy), determination, perseverance, and hard work as universal entrepreneurial values. Added to the line of the list of values is offered by Covin and Selvin (1989) such as innovativeness, risk-taking, and proactivity. These values are not different from the values presented by Schumpeter (1980) such as independence, innovativeness, rejection of the status quo, and risk-taking (Schumpeter, 1980), and as pointed out by McClelland (1961) such as achievement orientation, innovativeness, and commitment to learning. From these researchers, one can identify the universal values that are held by entrepreneurs across the border such as innovativeness, risk-taking, independence, achievement orientation, or self-determination.

Studies have shown that entrepreneurial values and business intention are correlated as pointed out by Jaen, et.al. (2015) particularly the value of openness to change and self-enhancement. The same authors (researchers), Jaen, et.al. (2014) went further into finding the influence of values and motivation toward business intention or entrepreneurial intention. Their study contends that values may explain the formation of intention antecedence such as attitude and moderate the effect on entrepreneurial intention. They pointed out that values and motivation are linked and may play a role in entrepreneurial intention. In this case, values serve as motivation to go into business. This is confirmed by the study of Gonzalez and Kobylinska (2019) that personal factors such as motivation and self-efficacy affect the intention of students to go into business in the future. The earliest study on the correlation between values and development was made by Weber (1905) as cited by Anchorena and Ronconi (2012). In such a study, Weber hypothesized that Protestant ethics such as hard work, thriftiness, patience, and perseverance are the spiritual basis for the development of capitalism. 


\subsection{Entrepreneurial Values Education}

Based on the concept of Hofstede (1984) that values are the product of certain cultures, therefore there can be differences of values from one place to another place, from one country to another country ((Eroglu \& Picak, 2011). In other words, the social environment plays important role in the formation of values (Türkkahraman, 2014) which Jocksimovic and Janjetovic (2008), as cited by Jovkovska and Barakoska (2014) argued that values are learned through social learning which happens through the influence the agents of socialization. Agents of socialization can be parents, teachers, adult persons, and important persons in society. Or it can also happen through drastic changes in society which force human beings to shift their views, attitudes about things and the world (Semple, 2019). Thus, based on these theories, we confidently argue that values are learned and not born and therefore, they can be changed when the social environments change too (Calman, 2004) and when their priorities or importance change (Schwartz, 1995).

Based on these sociological theories of values, then we can also argue that there is nothing wrong to change or introducing new values to students and it is the role of education to inculcate new values to the students as emphasized by Desjardins (2015) that education is to reproduce the "good" and transform the bad. JovKovska and Barakoska (2014) pointed out that it is the role of education in the formation of values and value orientation of students. Institutional educations are the agent of the socialization of values (Jocksimovic \& Janjetovic, 2008, cited by Jovkovska \& Barakoska, 2014). Thus, the concern of the school or the teacher, in particular, is not only providing scientific knowledge that preoccupies the mind or the head of a child or student but to transfer good social values and transform the bad values of a child or students into good values. Bad values should be replaced by good values. This is the concern of curriculum designers and developers. The philosophy behind curriculum development is the question of what kind of students that the school is going to produce. Therefore, the concern of education is how to reform or reorient the values of the students. Transforming the values of students must be the basic motivation in determining the curriculum (Halstead \& Taylor, 2000). It is in line with this concept, the Organization for Economic Co-operation and Development (OECD (2019) re-emphasized that attitude and values must be integrated into the curriculum development because education is not only about knowledge and skills but is also about values. In this case, the school should balance its attention to both concerns which are, on one hand, values and attitudes, and on the other hand, knowledge, and skills. OECD (2019) further emphasized that knowledge, skills, attitude, and values are not competing with each other but they are interrelated. OECD (2019) as cited from Haste (2018), defines values as "the guiding principles that underpin what people believe to be important when making decisions in all areas of private and public life. They determine what people will prioritize in making a judgment, and what they will strive for in seeking improvement".

Following the above concepts that we have presented; therefore, the concern of entrepreneurial education is not only about providing students with technical knowledge and skills but also with their entrepreneurial values which consequently transform the mindset or attitude of students. According to Erkkila (2000), entrepreneurial education encompasses both enterprise and entrepreneurship education. On one hand, entrepreneurial education concentrates on personal development, mindset, creativity, self-reliance, initiative-taking, action orientation, innovativeness (enterprise). On the other hand, entrepreneurial education is preparing students to put up a business and become self-employed (entrepreneurship) (QAA, 2012, Mahieu, 2006). It focuses on practical knowledge on how to establish a business. In a certain place or country, like Finland, to reflect both concerns, it uses the term internal entrepreneurship education and external entrepreneurship education to reflect both concerns. Internal entrepreneurship education reflects the purpose of entrepreneurial education as the venue for personal development, mindset, values, and skills. External entrepreneurship education emphasizes the purpose of education as preparing students the knowledge on how to establish a business and become the owner of a business (Seikkula-Leino et al., 2010, cited by Lackeus, 2015). However, the concept of entrepreneurship as an external entrepreneurship education had been challenged by Shane and Venkataraman, (2007) that entrepreneurship does not mean to create new business because when entrepreneurship is understood as personal development and mindset, then entrepreneurship can also occur in an existing organization. Entrepreneurship can be practiced within the existing organization in which the individual employees are allowed to create and innovate the product and services which may lead the organization to grow and create value (Gartner, 1990). In other words, an entrepreneurial individual does not mean only those who have created business but the entrepreneurial individual also refers to those who are creative, and innovative within the existing organization. This must be the concern of entrepreneurial education, however, conflicting definitions of entrepreneurship education lead to disagreement or conflicting ideas about the content of entrepreneurial education which consequently leads to the confusion of teachers on the approach to entrepreneurial education in terms of method, and assessment (Fayolle \& Gailly, 2008, cited by Lackeus, 2015). 
Thus, the definition that the current research adopts in this paper is the definition offered by the entrepreneurial education of Erkkila (2000). His definition covers two-aspect which are entrepreneurial education as personal development and entrepreneurial education to provide students with knowledge on how to establish a business. Concerning entrepreneurial education as personal development, thus, the concern of entrepreneurial education is not only technical knowledge of how to create a business but inculcating entrepreneurial values to students. Thus, the focus is entrepreneurial value formation. When talking about value formation, one's mind goes to the family as the basic foundation of value formation, besides peers and the environment but related to the value formation, it is also the role of schools to filter values that are socially accepted (Jovkovska \& Barakoska, 2014). It is the same with entrepreneurial values. The school should be able to adopt entrepreneurial values for the student to internalize and to live with. It will be their values that will guide them on how they are going to conduct their business (Didar, 2020). These values are responsible for managing their behaviors and at the same time as a source of motivation (Rokeach, 1973). According to Rozan \& Zibarzani, (2018) that entrepreneurial values or an entrepreneurial mindset are an important factor in producing a successful entrepreneur. Entrepreneurial values or entrepreneurial mindsets are personal values or mind-set of an entrepreneur that guide or motivate him to work.

The question of how to introduce entrepreneurial values to students would depend on how the school defines the purpose of entrepreneurial education. The strategy can be determined once the school has defined the purpose and the meaning of entrepreneurial education. This is important because the concern of teaching strategy would depend on a clear purpose and definition of entrepreneurial education which should be to foster entrepreneurial values such as perseverance, independence, determination, hard work (Ronconi and Anchorena (2012), innovativeness, risk-taking, proactivity, rejection of status-quo (Covin and Selvin,1989, Schumpeter (1980), achievement orientation and commitment to learning (McClelland, 19610.

\subsection{Cognitive Attitude toward Business}

As we have pointed out above that going into business is not a matter of values but it is a matter of knowledge. This is another objective of education. At the end of the course, students must have a cognitive attitude toward business. To understand what a cognitive attitude toward business is, one needs to know the concept of attitude first. Cherry (2020) defines attitude as "a set of emotions, beliefs, and behaviors toward a particular person, object, thing or event". When a person often encounters certain experiences with people or with the social environment around him/her, slowly the person forms a certain general view or idea about the person or about the objects she/he encounters. Thus, attitude involves learning, and such learning results in perception (Ortmeyer, 1949). It is, therefore, Cherry (2020) contends that attitude is a product of experience or upbringing. The concern of education would be to determine a kind of education that can form or change the attitude of students toward the business. This concept suggests that entrepreneurial education is not limited to the classroom but involves experience or exposure.

Related to the role of attitude, Titchener (1910) as cited by Ortmeyer (1949) argued that attitude is behind everything of human behavior which may not necessarily appear in consciousness, and it is often vague. Titchener (1910, cited by Ortmeyer, 1949) concluded that it is a manifestation of the unconscious mind. It is acquired and temporary in nature as Dewey (1922) contended that attitude is acquired and leads to action. Though it is unconscious, however, it is still a force that is directed toward an object (Koffka, 1935). According to Ajzen and Fishbein (1975, p. 6) attitude is a "- -a learned predisposition to respond in a consistently favorable or unfavorable manner to a given object". Further, Ajzen (2001) explained that it is a summary evaluation of a person toward a certain object whether it is favorable or unfavorable, good or bad, pleasant or unpleasant. It has three main components which include cognitive, affective, and conative. Cognitive stands for the general knowledge, thoughts, or beliefs of the person toward the object, person, or events. While effective component represents the feeling or emotion of the person, toward a person, object, or event. Lastly, conative dimensions refer to the behavior or action of the individual toward the object, the person, or event (Ajzen, 1993). Allport (1968) argued that attitude is a predicting factor of behavior which means that human behavior is emanated from his/her attitude or beliefs. Ajzen (1993) also supports the idea of Allport (1968) on the validity of attitude as a predicting factor of behavior. This was Allport's defense to Wicker (1969) who expressed doubts about the correlation between attitude and behavior. Wicker (1969) called for the abandonment of the study on attitude and behavior relation. However, as a result of many discussions on the pro and cons supported by data on the issue, finally, the study about the relationship between attitude and behavior was maintained and continued. The group that defends the correlation between attitude and behavior argue that if there is any inconsistency between attitude and behavior, it is because of the response biases at the time the respondents answer the questions, and it can also be caused by the instruments used which often time measure attitude as a single construct, instead of the multidimensional construct. Furthermore, 
the inconsistency was also caused by moderating variables such as self-awareness, and self-monitoring tendency, time pressure (Ajzen, 1993).

After we have discussed the concept of attitude, now we have an idea of what cognitive attitude toward business is. As we have mentioned above the dimensions of attitude are cognitive, affective, and conative, and now we discuss deeper the cognitive dimension of attitude particularly cognitive attitude toward business. As pointed out above, a cognitive attitude refers to the general knowledge of the person toward the attitude object. It is about the belief, thoughts, or ideas about the attitude object (McLeod, 2018). The cognitive attitude of the person comes from direct or maybe indirect experience. However, according to McLeod (2018) attitude which is gained from direct experience is more strongly held by the person compared to an attitude that comes from reading, listening, or watching, and an attitude that comes from direct experience has more influences over the behavior of the person. This is in line with what was pointed out by Cherry (2020), that attitude is the result of experience or upbringing. As a result of those experiences is the attitude of the person toward its object and, it provides meaning for the person toward the object and it can influence the behavior of the person toward the object (Katz, 1960). Based on their concept about attitude as a result of experience, then attitude toward business means the general knowledge of the students about the business, and such attitude should be the result of direct experience and indirect experience of the students toward business. Direct experience would include students' exposure to the business and indirect experience gains from reading the books and lectures. However, as is stated earlier that direct experience is more powerful than indirect experience to influence behavior. In other words, the attitude of students toward business must be the result of direct experience toward business which is direct exposure to the business. This is what Dewey (1938) means by learning by doing. Dewey (1938) had criticized traditional education which focused on the subject matter, and methodologies and neglect experiential learning. According to Dewey (1938) as cited by Williams (2017) that traditional education is not developmentally appropriate for young learners. Thus, Dewey proposed socially engaging learning which occurs through social interaction (Williams, 2017). In this case of entrepreneurial education, direct interaction between business students and the business activities itself.

\subsection{Business Behavioural Intention}

As pointed out by Allport (1968) and Ajzen (1993) that attitude leads to action. In other words, the cognitive attitude of students toward business must lead toward the business behavioral intention. To understand the concept of business behavioral intention, it is important to understand different theories of behavior. These behavioral theories were summarized by National Research Council (2003) and it is a summary of the theories of behavior that are presented by several theorists such as Ajzen, $(1985,1991)$ on the theory of planned behavior, Bandura, (1977, 1986, 1991, 1994) on social cognitive theory, Fishbein and Ajzen, (1975), Ajzen and Fishbein, (1980), Fishbein et al., (1991) on the theory of reasoned action, Becker, (1974, 1988), Rosenstock, (1974) on the health belief model, Triandis, (1972), on the theory of subjective culture and interpersonal relations. These theories are too many and can be overlapping. Consequently, there is an agreement among theorists to identify which theories and variables are presented in those theories that are influencing behavior (Fishbein, 2000), Fishbein et al., (2001). The theorists agreed that there are three theories chosen such as social cognitive theory, reason-action theory, and the health belief model. Based on the social cognitive theory (Bandura, $(1977,1986,1991,1994)$, there are two determining variables influencing the behavior and they are self-efficacy and the incentive of performing such behavior. The first is self-efficacy. The person can perform such behavior under any circumstances. A person can only perform such behavior if he/she believes that he/she can do it or he/she can do it. Second is the incentive of performing such behavior. This refers to the benefits that one can get from performing such behavior. One can only perform a certain behavior if he/she believes that he/she will get more benefits from performing such behavior (National Research Council 2003). According to the theory of reasoned action, the determining variable that predicts a behavior is the strength of one's intention to perform or not to perform. The strength of intention means the likelihood that one will perform the behavior. However, the strength of the intention is determined by one's attitude toward performing the behavior. The action will be performed if he/she believes that performing such action will lead to a better outcome. Next is that the strength of intention is also determined by one's subjective norms performing such behavior (National Research Council 2003), in the sense that one might have certain rules on performing such behavior. If the person believes that such action is recommended or approved by others, then he/she will likely perform such action. Lastly is the health belief model. According to this theory, one can perform a given behavior to prevent serious health consequences of not performing such behavior. In other words, one will perform such action if she/he knows that it will protect him/her from sickness (National Research Council 2003).

Thus, in short, from those theories, we can summarize that there are four determining factors that may influence individual intention and behavior and they are first, the attitude of the person toward performing the behavior, if the behavior will lead to a greater positive outcome or not. Second, is the perceived norms, in the sense that one 
will act when he/she knows that others will support his/her action or the society approve of such action? The third is self-efficacy. This refers to the belief of the person toward himself/herself if she can perform such action in any given situation. Fourth is the prevention of any serious health consequences. A person will perform certain behavior when he/she believes that it is the only way to prevent any sicknesses (National Research Council, 2003).

From the theories of behavior, then we can formulate our concept of business behavioral intention. It simply says that business behavioral intention is the intention to go into business. The intention to go into business will be dependent on their attitude toward doing a business, the individual norms that someone has about doing business, self-efficacy (the ability to perform business ventures), and perceived health benefits from doing business. In addition to what is identified as determinant factors to go into business, Lin, et.al. (2017) consider the following factors that influence someone's intention to go into business such as capabilities, attitudes, perceptions and aspirations, resources, environmental conditions, and social values. These factors are similar to what Ozaralli and Rivenburgh (2016) identified as determinant factors that can motivate someone to go into business such as social factors (experience and education), societal (economic and political climate), and personality factors.

\section{Conceptual Framework}

\section{Independent Variables Dependent Variables}

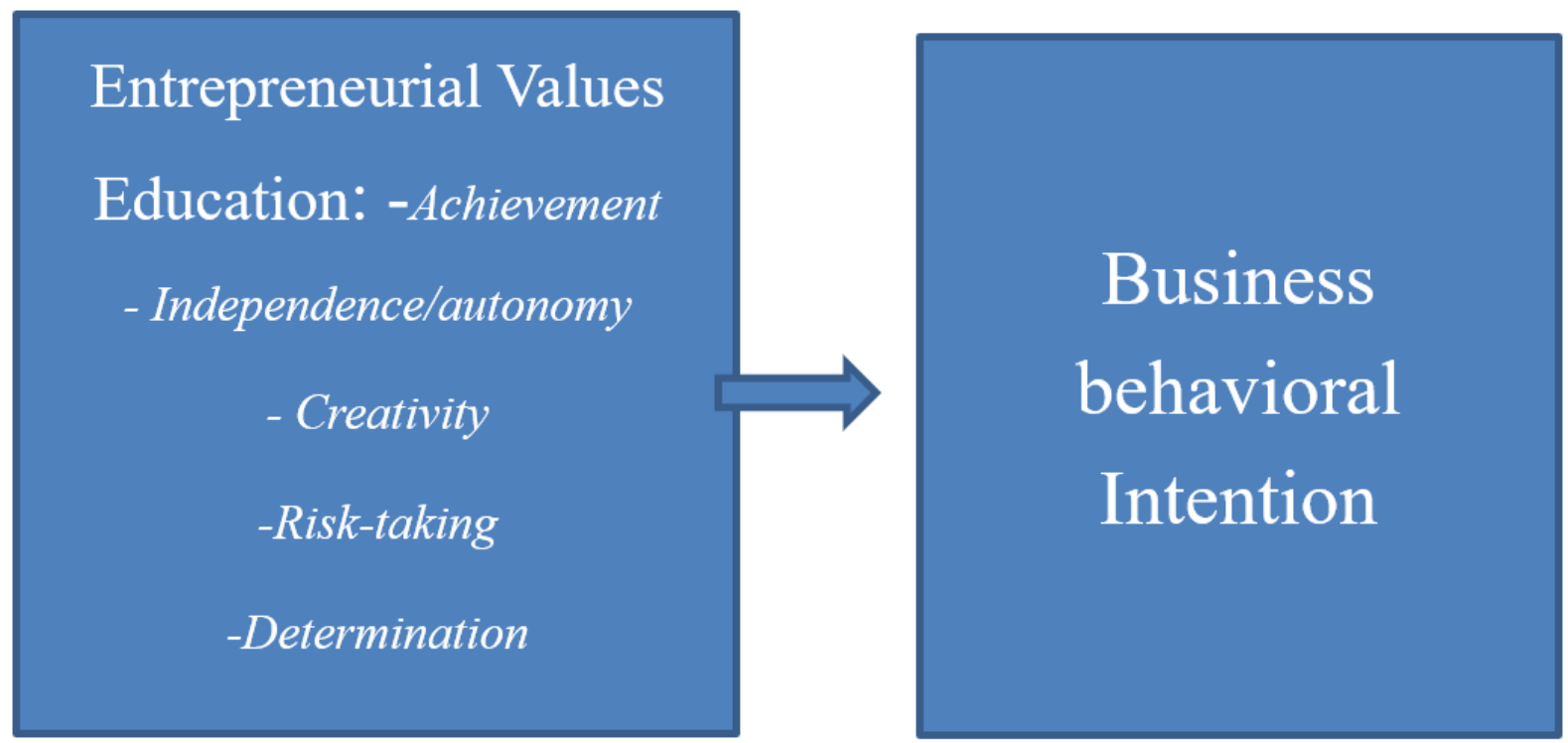

Figure 1. The conceptual framework of the study reflects the influence of independent variables toward the dependent variable or the influence of entrepreneurial attitude and cognitive attitude toward the business behavioral intention. In this case, any positive change along with entrepreneurial values and cognitive attitude toward business can affect the business intention of students.

Source: Ajzen (2001), Ronconi and Anchorena (2012), Schumpeter (1980) and Lin, et.al. (2017).

\subsection{Statement of the Problems}

The study intends to measure the correlation between entrepreneurial values, cognitive attitude, and business behavioral intention. It specifically answers the following questions:

1. What are the entrepreneurial values of students?

2. What is the cognitive attitude of students toward business?

3. What is the business behavioral intention of students?

4. Is there a difference between grade XII students and college students in terms of entrepreneurial values, cognitive attitude toward business?

5. Is there a correlation between entrepreneurial values, cognitive attitude toward business, and business behavioral intention? 


\subsection{Assumption}

The study assumes that entrepreneurial values and cognitive attitudes affect the business behavioral intention of students and it can be measured. It is also assumed that questionnaires reflect the content of the theory and the answer to the questionnaires are objective.

\subsection{Hypothesis}

Values are the source of motivation and it predicts the behavior of the person and guide the person in decision making (Mankoff, 1974). However, values alone are not enough if it is not guided by knowledge. Ajzen (1993) also contends that cognitive attitude also predicts the behavior of the person. Based on these theories, the current research hypothesizes that there is a correlation between entrepreneurial values, cognitive attitude, and the business behavioral intention of the students.

\subsection{Scope and Delimitation of the Study}

The study covers Divine Word College of Laoag in the Ilocos Norte and its students particularly ABM grade XII and Fourth Year college students of Business management course who have taken entrepreneurship courses. The study delimits itself to discover only their entrepreneurial values and cognitive attitude toward business and its influence on business behavioral intention.

\section{Research Methodology}

The research methodology is a specific procedure or technique to be followed in conducting a scientific investigation about a certain topic. Following a certain technique of investigation determines the validity and reliability of the study. Research methodology identifies how data are gathered and analyzed (Leedy, 1974). In line with this concept, this part includes research design, the population of the study, and the locale of the study, data gathering procedures, data gathering instruments, and statistical treatment of data.

\subsection{Research Design}

The study is quantitative research and it used descriptive assessment and correlational research design. Baht (2020) defines descriptive research as a "research method that describes the characteristics of the population or the phenomena that are studied. It focuses more on the "what" of the research subject rather than the "why" of the research subject" (para. 1). This research design is used to determine the extent of entrepreneurial values, cognitive attitude, and business behavioral intention of students who have taken the entrepreneurship course. The nature of descriptive research is to describe what is found in the data collected through questionnaires and statistical treatment. It is also used to describe profiles, frequency distribution, describe characteristics of people, situations, phenomena, or relationship variables. In short, it describes "what is" about the data (Ariola, 2006) cited by (Abun et al., 2019).

Concerning the current study, the descriptive correlational method was deployed. The study determines the level of entrepreneurial values, the cognitive attitude of students toward business, and how it affects their business behavioral intention.

\subsection{The locale of the Study}

The locale of the study was the Divine Word College of Laoag in Ilocos Norte.

\subsection{Population}

The population of the study was composed of all ABM grade XII students who have taken entrepreneurship subjects and fourth-year college students who have taken the entrepreneurship course. Thus, the total enumeration sampling was used.

\subsection{Data Gathering instruments}

The study adopted validated questionnaires of Abun, et.al (2018) on entrepreneurial attitude and entrepreneurial intention of grade XII students.

\subsection{Data Gathering Procedures}

In the process of data gathering, the researcher sent a letter to the President of the College, requesting them to allow the researcher to flow his questionnaires in the college. The researcher personally met the President and employees and requested them to answer the questionnaires.

The retrieval of questionnaires was arranged between the President's representative and the researcher with the help of employees and faculty of the college. 


\subsection{Statistical Treatment of Data}

In consistence with the study as a descriptive assessment and correlational research design, therefore descriptive statistics and inferential statistics were used. The weighted mean is used to determine the extent of entrepreneurial values, cognitive attitude toward business, and business behavioral intention, and the Multiple Regression was used to measure the correlation between entrepreneurial values, cognitive attitude, and business behavioral intention. Multi regression measures the correlation between multiple independent variables and one dependent variable (Statistic Solutions, n.d).

The following ranges of values with their descriptive interpretation will be used:

\begin{tabular}{ll}
\hline Statistical Range & Descriptive Interpretation \\
\hline $4.21-5.00$ & Strongly agree/very high \\
$3.41-4.20$ & Agree/High \\
$2.61-3.40$ & Somewhat agree/Moderate \\
$1.81-2.60$ & Disagree/Low \\
$1.00-1.80$ & Strongly disagree/Very Low \\
\hline
\end{tabular}

\subsection{Empirical Data and Analysis}

This part presents empirical data as the basis for analysis. This part is very important because as an empirical study, it must be supported by evidence that is collected through questionnaires. The empirical analysis is an integral part of the scientific methods however, it never gives an absolute answer but it gives only a most likely answer based on probability (Whatls.com, n.d). The presentation is following the statement of the problems.

\section{Problem 1: What are the entrepreneurial values of students?}

Table 1. Summary Table of Entrepreneurial Values

\begin{tabular}{lll}
\hline Entrepreneurial Values & Mean & Descriptions \\
\hline Achievement-Oriented & 4.04 & A \\
Autonomy-Oriented & 3.07 & SWA \\
Creativity-Oriented & 3.47 & A \\
Risk Taking-Oriented & 3.80 & A \\
Determination & 3.96 & A \\
Overall & 3.60 & A \\
\hline
\end{tabular}

Source: Abun, et.al (2018).

Legend:

\begin{tabular}{ll}
\hline Statistical Range & Descriptive Interpretation \\
\hline $4.21-5.00$ & Strongly agree/very high \\
$3.41-4.20$ & Agree/High \\
$2.61-3.40$ & Somewhat agree/Moderate \\
$1.81-2.60$ & Disagree/Low \\
$1.00-1.80$ & Strongly disagree/Very Low \\
\hline
\end{tabular}

Base on the data on the table, it shows that entrepreneurial values education of students in terms of achievement orientation obtained a mean of 4.04 which is described as "agree/high". This indicates that as a whole the achievement orientation values of the grade XII ABM and the fourth-year college students of business management course is not very high and it is not also very low, low, or moderate but it is high. This suggests that the ABM grade XII and the fourth-year College of business management students have high achievement orientation values. This means that the ABM grade XII and the fourth-year college students of the business management course highly agree that they have goals to achieve and all their activities are inspired by the goals that they have set for themselves.

In terms of autonomy orientation values, the data on the table reveals that the entrepreneurial values education of students in terms of autonomy orientation values gained a mean rating of 3.07 which is understood as "somewhat agree/moderate". This rating implies that the autonomy orientation values of the ABM grade XII and the fourth- 
year college of business management course is not very high or high and it is also not very low or low but it is at a moderate level. This rating signifies that the ABM grade XII and the fourth-year college students of business management course somewhat agree on the extent of their autonomy orientation values. Their autonomy values are moderate. It suggests that they somewhat agree or moderately agree to accomplish their goals unconventionally and work independently without the help of others, ignore criticism to achieve their goals, and freely express what they think even if they are being criticized.

Concerning their creativity orientation, the data on the table demonstrates that entrepreneurial values education of ABM grade XII and the fourth-year students of business management course in terms of creativity orientation value gained a mean rating of 3.47 which is translated as "agree/high". This mean rating implies that the entrepreneurial values of students in terms of creativity are not very high and it is also not very low, low, or moderate but it is high. In this case, the students highly agree that they are creative or they value creativity. They admitted that others find their ideas unusual, want to do things in a new way, can easily adapt to new changes, raise many questions that other people do not like to hear, and are not interested to follow what others are doing.

Related to risk-taking, the data on the table displays that entrepreneurial values education in terms of risk-taking value received a mean rating of 3.80 which is understood as "agree/high". The mean rating points out that the risktaking value of the students is not very high and it is not also very low, moderate but it is high. This means that students' risk-taking value is high. They agree that they have to set the targets even if it is not certain, even if there is no money, they can borrow money to implement their ideas to achieve their goals and try to do things even if the chance to succeed is slim. They agree to take the opportunity that might lead them to better things and they do not mind asking a favor from others even if it means rejection, and as much as possible to take decision quickly to exploit the opportunity and want to take a project that might be risky.

Lastly is the determination value. As displayed on the table, the data appears that entrepreneurial values education of the students in terms of determination value obtained a mean rating of 3.96 which is described as "agree/high". This mean rating demonstrates that the entrepreneurial values of the students in terms of determination are not very high and it is also not very low, low, or moderate but it is high. In this case, the determination value of the students is high. In other words, they agree that if they want to be successful they have to take chances when they occur and work hard. They also believe that people generally get what they deserve and getting what they want or not getting what they want is not a matter of luck or bad luck and it is also not determined by other people but by hard work and determination. After all, success is not determined by place and time or luck or bad luck but it is a matter of you wanting it and pursuing it.

In summary, the data demonstrate that overall the entrepreneurial values education of students obtained an overall mean rating of 3.60 which is described as somewhat agree/high". This suggests that the entrepreneurial values of students, ABM grade XII and the fourth-year college students of business management course are not very high and it is not also very low, low, or moderate but it is high. This rating suggests that students have high achievement orientation values, autonomy orientation values, creativity orientation values, risk-taking orientation, and determination values.

\section{Problem 2: What is the cognitive attitude of students toward business?}

Table 2.

\begin{tabular}{lll}
\hline Indicators & Mean & Descriptions \\
\hline 1. Business creates jobs and makes money & 4.21 & $\mathrm{~A}$ \\
2. Business means to be self-employed & 3.85 & $\mathrm{~A}$ \\
3. Businesses gather resources to create wealth & 4.02 & $\mathrm{~A}$ \\
4. Business can make someone independent & 3.99 & $\mathrm{~A}$ \\
5. Business contributes to economic development & 4.22 & $\mathrm{~A}$ \\
6. Business is making yourself as an employer of labor & 3.95 & $\mathrm{~A}$ \\
7. Entrepreneurs attends social functions to meet business people & 4.05 & $\mathrm{~A}$ \\
8. Business owner uses his/her creative ability to create new products & 4.31 & $\mathrm{~A}$ \\
Overall & $\mathbf{4 . 0 0}$ & $\mathrm{A}$ \\
\hline
\end{tabular}

Source: Abun, et.al (2018). 
Legend:

\begin{tabular}{ll}
\hline Statistical Range & Descriptive Interpretation \\
\hline $4.21-5.00$ & Strongly agree/very high \\
$3.41-4.20$ & Agree/High \\
$2.61-3.40$ & Somewhat agree/Moderate \\
$1.81-2.60$ & Disagree/Low \\
$1.00-1.80$ & Strongly disagree/Very Low \\
\hline
\end{tabular}

As shown by the data on the table, it appears that as a whole the cognitive attitude of students toward business obtained an overall mean rating of 4.00 which is described as "agree/high". This mean rating indicates that the cognitive attitude of the ABM grade XII and the fourth-year college students of the business management course is not very high and it is also not very low, low, or moderate but it is high. This rating suggests that as a whole the students have a high idea about business. As individual indicators demonstrate that students believe that business creates jobs, wealth and contributes to economic development. They further believe that business makes them selfemployed, independent, boss of their own business and makes them creative and attend social functions to meet other business people.

\section{Problem 3: What is the business behavioral intention of students?}

Table 3.

\begin{tabular}{lll}
\hline Indicators & Mean & Descriptions \\
\hline BI1. My professional goal is to become an entrepreneur & 4.3162 & $\mathrm{~A}$ \\
BI2. I will make every effort to start and run my own business & 4.1026 & $\mathrm{~A}$ \\
BI3. I am determined to establish a business in the future & 4.0769 & $\mathrm{~A}$ \\
BI4. I am seriously considering putting up a business in the future & 4.1624 & $\mathrm{~A}$ \\
BI5. I have the firm intention to start a firm someday & 4.1026 & $\mathrm{~A}$ \\
BI6. I am ready to do anything to be an entrepreneur & 3.9060 & $\mathrm{~A}$ \\
BI7. If I will open a business, I have a chance to become successful & 3.2991 & $\mathrm{SWA}$ \\
BI8. Being an entrepreneur would make me great & 4.0769 & $\mathrm{~A}$ \\
BI9. I have ideas about how to start a business in the future & 3.8889 & $\mathrm{~A}$ \\
BI10. It would be difficult for me to develop business ideas & 3.3162 & $\mathrm{~A}$ \\
Business Intention OVERALL & $\mathbf{3 . 9 2 4 8}$ & $\mathrm{A}$ \\
\hline
\end{tabular}

Source: Abun, et.al (2018).

Legend:

\begin{tabular}{ll}
\hline Statistical Range & Descriptive Interpretation \\
\hline $4.21-5.00$ & Strongly agree/very high \\
$3.41-4.20$ & Agree/High \\
$2.61-3.40$ & Somewhat agree/Moderate \\
$1.81-2.60$ & Disagree/Low \\
$1.00-1.80$ & Strongly disagree/Very Low \\
\hline
\end{tabular}

As demonstrated by the data on the table, it reveals that overall the business behavioral intention of students received an overall mean rating of 3.92 which is considered "agree/high". This rating indicates that overall the students' business behavioral intention is not very high and it is also not very low, low, or moderate but it is high. This signifies that the students have a high business behavioral intention. In other words, overall, they plan to go into business in the future. The students admitted that they highly agree to be an entrepreneur in the future, to operate their own business, and believe that having their own business in the future makes them great.

Problem 4. Is there a difference between grade XII students and college students in terms of entrepreneurial values, cognitive attitude toward business? 
Table 4. The Difference of entrepreneurial values ( Group Statistics)

\begin{tabular}{llllll}
\hline & Level & $\mathrm{N}$ & Mean & Std. Deviation & Std. Error Mean \\
\hline \multirow{2}{*}{ Achievement-Oriented } & Grade 12 & 19 & 3.9526 & .63102 & .14477 \\
& BS Management & 98 & 4.0622 & .67435 & .06812 \\
\multirow{2}{*}{ Autonomy-Oriented } & Grade 12 & 19 & 3.2216 & .66639 & .15288 \\
& BS Management & 98 & 3.0488 & .63437 & .06408 \\
\multirow{2}{*}{ Creativity-Oriented } & Grade 12 & 19 & 3.5963 & .59479 & .13646 \\
& BS Management & 98 & 3.4493 & .59967 & .06058 \\
\multirow{2}{*}{ Disk Taking-Oriented } & Grade 12 & 19 & 3.7158 & .35318 & .08103 \\
& BS Management & 98 & 3.8184 & .49520 & .05002 \\
& Grade 12 & 19 & 3.8368 & .64825 & .14872 \\
& BS Management & 98 & 3.9857 & .70257 & .07097 \\
\hline
\end{tabular}

Independent Samples Test

\begin{tabular}{|c|c|c|c|c|c|c|c|c|c|c|}
\hline & \multicolumn{2}{|c|}{\begin{tabular}{|ll} 
Levene's & \\
Test & for \\
Equality & of \\
Variances & \\
\end{tabular}} & \multicolumn{7}{|c|}{ t-test for Equality of Means } \\
\hline & & \multirow{2}{*}{$\mathrm{F}$} & \multirow{2}{*}{ Sig. } & \multirow{2}{*}{ t } & \multirow{2}{*}{$\mathrm{df}$} & \multirow{2}{*}{$\begin{array}{l}\text { Sig. } \\
\text { tailed) }\end{array}$} & \multirow{2}{*}{$\begin{array}{l}\text { (2- } \text { Mean } \\
\text { Difference }\end{array}$} & \multicolumn{3}{|c|}{$\begin{array}{l}\text { Std. Error } 95 \% \text { Confidence } \\
\text { Difference Interval of the } \\
\text { Difference }\end{array}$} \\
\hline & & & & & & & & & Lower & Upper \\
\hline \multirow{2}{*}{$\begin{array}{l}\text { Achievement- } \\
\text { Oriented }\end{array}$} & $\begin{array}{l}\text { Equal variances } \\
\text { assumed }\end{array}$ & .406 & .525 & -.655 & 115 & .514 & -.10961 & .16739 & -.44117 & .22195 \\
\hline & $\begin{array}{l}\text { Equal variances } \\
\text { not assumed }\end{array}$ & & & -.685 & 26.611 & .499 & -.10961 & .15999 & -.43811 & .21889 \\
\hline \multirow{2}{*}{$\begin{array}{l}\text { Autonomy- } \\
\text { Oriented }\end{array}$} & $\begin{array}{l}\text { Equal variances } \\
\text { assumed }\end{array}$ & .192 & .662 & 1.078 & 115 & .283 & .17280 & .16030 & -.14472 & .49033 \\
\hline & $\begin{array}{l}\text { Equal variances } \\
\text { not assumed }\end{array}$ & & & 1.042 & 24.739 & .307 & .17280 & .16577 & -.16879 & .51439 \\
\hline \multirow{2}{*}{$\begin{array}{l}\text { Creativity- } \\
\text { Oriented }\end{array}$} & $\begin{array}{l}\text { Equal variances } \\
\text { assumed }\end{array}$ & 306 & .581 & .979 & 115 & .329 & 14703 & .15013 & -.15035 & .44441 \\
\hline & $\begin{array}{l}\text { Equal variances } \\
\text { not assumed }\end{array}$ & & & .985 & 25.609 & .334 & .14703 & .14930 & -.16008 & .45414 \\
\hline \multirow{2}{*}{$\begin{array}{l}\text { Risk Taking- } \\
\text { Oriented }\end{array}$} & $\begin{array}{l}\text { Equal variances } \\
\text {-assumed }\end{array}$ & 2.703 & .103 & -.860 & 115 & .392 & -.10258 & .11926 & -.33882 & .13366 \\
\hline & $\begin{array}{l}\text { Equal variances } \\
\text { not assumed }\end{array}$ & & & -1.077 & 33.435 & .289 & -.10258 & .09522 & -.29621 & .09106 \\
\hline \multirow{2}{*}{ Determination } & $\begin{array}{l}\text { Equal variances } \\
\text { assumed }\end{array}$ & 210 & .648 & -.855 & 115 & .394 & -.14887 & .17405 & -.49364 & .19589 \\
\hline & $\begin{array}{l}\text { Equal variances } \\
\text { not assumed }\end{array}$ & & & -.903 & 26.873 & .374 & -.14887 & .16479 & -.48706 & .18932 \\
\hline
\end{tabular}

Source: IBM SPSS Software

As indicated by the data on the table, the descriptive statistics on the significant difference of entrepreneurial values between ABM Grade XII and the fourth-year college students of business management course shows no significant difference in entrepreneurial values along with the five domains between the Grade 12 and college students ( $p>.05$ ). This indicates that the entrepreneurial values of students are not affected by the level of business education. 
Table 5. Cognitive Attitude Group Statistics

\begin{tabular}{llrrrr}
\hline \multirow{4}{*}{ Cognitive Attitude } & Level & N & Mean & Std. Deviation & \multicolumn{1}{c}{ Std. Error Mean } \\
\cline { 2 - 6 } & Grade 12 & 19 & 3.9895 & .49988 & .11468 \\
& BS Management & 98 & 4.1133 & .71791 & .07252 \\
\hline
\end{tabular}

Independent Samples Test

\begin{tabular}{|c|c|c|c|c|c|c|c|c|c|c|}
\hline & \multicolumn{9}{|c|}{$\begin{array}{l}\text { Levene's Testt-test for Equality of Means } \\
\text { for Equality } \\
\text { of Variances }\end{array}$} \\
\hline & & $\mathrm{F}$ & Sig. & t & df & $\begin{array}{l}\text { Sig. } \\
(2- \\
\text { tailed })\end{array}$ & 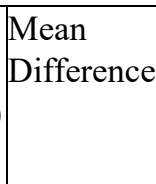 & $\begin{array}{l}\text { Std. Error } \\
\text { Difference }\end{array}$ & $\begin{array}{l}95 \% \\
\text { Confider } \\
\text { Interval } \\
\text { Differen }\end{array}$ & $\begin{array}{l}\text { nce } \\
\text { of the } \\
\text { ace }\end{array}$ \\
\hline & & & & & & & & & Lower & Upper \\
\hline \multirow{2}{*}{ Cognitive Attitude } & $\begin{array}{l}\text { Equal } \\
\text { assumed }\end{array}$ & 1.169 & 282 & -.717 & 115 & .475 & -.12379 & .17255 & -.46558 & .21800 \\
\hline & $\begin{array}{l}\text { Equal variances not } \\
\text { assumed }\end{array}$ & & & -.912 & 34.257 & 7.368 & -.12379 & .13569 & -.39946 & .15188 \\
\hline
\end{tabular}

Source: IBM SPSS Software

Based on the data, it also reveals that there is NO significant difference in the cognitive attitude between the Grade 12 and college students $(p>.05)$. This suggests that level of education does not affect students' attitude toward business.

Table 6. Business Intentions Group Statistics

\begin{tabular}{llrrrr}
\hline & Level & $\mathrm{N}$ & \multicolumn{1}{c}{ Mean } & \multicolumn{1}{c}{ Std. Deviation } & \multicolumn{1}{c}{ Std. Error Mean } \\
\hline \multirow{2}{*}{ Business Intention } & Grade 12 & 19 & 3.7895 & .51950 & .11918 \\
& BS Management & 98 & 3.9510 & .62972 & .06361 \\
\hline
\end{tabular}

Independent Samples Test

\begin{tabular}{|c|c|c|c|c|c|c|c|c|c|c|}
\hline & \multicolumn{2}{|c|}{$\begin{array}{l}\text { Levene's } \\
\text { Test for } \\
\text { Equality of } \\
\text { Variances }\end{array}$} & t-test f & or Equal & ity of $\mathrm{N}$ & eans & & & \\
\hline & & \multirow[t]{3}{*}{$\mathrm{F}$} & \multirow[t]{3}{*}{ Sig. } & \multirow[t]{3}{*}{$t$} & \multirow[t]{3}{*}{ df } & \multicolumn{2}{|c|}{ Sig. (2-|Mean } & \multirow{2}{*}{\multicolumn{3}{|c|}{$\begin{array}{l}\text { Std. Error } 95 \% \text { Confidence } \\
\text { Difference Interval of the } \\
\text { Difference }\end{array}$}} \\
\hline & & & & & & tailed) & Difference & & & \\
\hline & & & & & & & & & Lower & Upper \\
\hline \multirow{2}{*}{$\begin{array}{l}\text { Business } \\
\text { Intention }\end{array}$} & $\begin{array}{ll}\begin{array}{l}\text { Equal } \\
\text { assumed }\end{array} & \text { variances } \\
\end{array}$ & .055 & .815 & -1.050 & 115 & .296 & -.16155 & .15386 & -.46630 & .14321 \\
\hline & $\begin{array}{ll}\begin{array}{l}\text { Equal variances } \\
\text { assumed }\end{array} & \text { not }\end{array}$ & & & -1.196 & 29.275 & .241 & -.16155 & .13510 & -.43773 & .11464 \\
\hline
\end{tabular}

Source: IBM SPSS Software

As indicated by the group statistics and independent sample test, it demonstrates that there is NO significant difference in the business intentions between the Grade 12 and fourth college students $(p>.05)$. This is also suggesting that business education level has nothing to do with the difference in business intention.

Problem 5: Is there a correlation between entrepreneurial values, cognitive attitude toward business, and business behavioral intention? 
Table 7. Correlation

\begin{tabular}{|c|c|c|c|c|c|c|}
\hline & \multicolumn{5}{|c|}{ ENTREPRENEURIAL VALUES } \\
\hline & & $\begin{array}{l}\text { Achievement- } \\
\text { Oriented }\end{array}$ & $\begin{array}{l}\text { Autonomy- } \\
\text { Oriented }\end{array}$ & $\begin{array}{l}\text { Creativity- } \\
\text { Oriented }\end{array}$ & $\begin{array}{l}\text { Risk Taking- } \\
\text { Oriented }\end{array}$ & Determination \\
\hline \multirow{3}{*}{$\begin{array}{l}\text { Cognitive } \\
\text { Attitude }\end{array}$} & Pearson Correlation & $.613^{* *}$ & .161 & $.419^{* *}$ & $.429^{* *}$ & $.777^{* *}$ \\
\hline & Sig. (2-tailed) & .000 & .083 & .000 & .000 & .000 \\
\hline & $\mathrm{N}$ & 117 & 117 & 117 & 117 & 117 \\
\hline \multirow{3}{*}{$\begin{array}{l}\text { Business } \\
\text { Intention }\end{array}$} & Pearson Correlation & $.629^{* * *}$ & $.278^{* *}$ & $.439^{* * *}$ & $.455^{* *}$ & $.673^{* * *}$ \\
\hline & Sig. (2-tailed) & .000 & .002 & .000 & .000 & .000 \\
\hline & $\mathrm{N}$ & 117 & 117 & 117 & 117 & 117 \\
\hline
\end{tabular}

*. Correlation is significant at the 0.05 level (2-tailed).

**. Correlation is significant at the 0.01 level (2-tailed).

As demonstrated by the data on the table, it manifests that statistically significant positive correlations exist between cognitive attitude and the entrepreneurial values of students along Achievement-oriented, Creativityoriented, Risk-Taking Oriented, and Determination, while no significant relationship exists between cognitive attitude, entrepreneurial value in terms of being autonomy-oriented

Students with high entrepreneurial values tend to have high cognitive attitudes as well; except along autonomy oriented, wherein cognitive attitudes do not vary significantly with this domain based on the results of the correlation analysis.

Business intentions of the students are significantly related to their entrepreneurial values along all of the five domains - achievement-oriented, autonomy-oriented, creativity-oriented, risk talking oriented, and determination. Students with high entrepreneurial values manifest high business intentions.

\section{Result and Discussion}

The purpose of entrepreneurship education is not just to disseminate textbook knowledge about business but to create awareness about the importance of business as a means to make money and create wealth and contribute to economic development. In other words, entrepreneurship education help students to increase their general knowledge about business and its importance to the individual life and common good of society. The general knowledge about the business must lead the students to form a positive cognitive attitude about business which consequently makes them love business and go into business. Besides providing general business knowledge, entrepreneurship education goes beyond providing general knowledge which is to help students to inculcate entrepreneurial values such as achievement, autonomy, creativity, risk-taking, and determination. Thus, this requires a certain method or strategy of teaching that can motivate students to imbibe/embrace those values into their life. These concerns have been discussed by Seikkula-Leino et al., (2010), cited by Lackeus, (2015) about internal and external entrepreneurship education to address both issues about the purpose of entrepreneurship education as a means to provide business knowledge and inculcate entrepreneurial values to students. However, it may not be easy to inculcate those values to students through entrepreneurship education alone. Thus, it is suggested to create an entrepreneurial mindset subject as a separate course to focus on issues or matters that may help develop the entrepreneurial values of students (Smithers \& Catanzaro, 2014).

The findings of this study provide us ideas that entrepreneurship education helps the students to form a general idea or belief about business and its purpose which is called cognitive attitude. It also helps inculcate the entrepreneurial values of students who have taken entrepreneurship courses. As indicated in the finding of the difference of values and cognitive attitude between the ABM Senior High School grade XII and the fourth-year college students of business management course pointed out that there is no significant difference. This indicates that the number of years in entrepreneurship education does not make a difference in terms of acquiring entrepreneurial values and cognitive attitude toward business. Even in terms of business intention, the result of the study pointed out that there is no significant difference. In other words, the length of entrepreneurship education does not create a difference in terms of intention to go into business in the future.

However, in terms of the relationship between entrepreneurial values and business intention, between cognitive attitude and business intention, the result of this study found that there is a correlation. It means that entrepreneurial values and cognitive attitude toward business are predictors of business intention. This is the function of entrepreneurship education which is to provide general knowledge or belief about business and its benefits for the 
individual and community and to develop entrepreneurial values. Thus, the challenge for curriculum developers is either to create a separate course entrepreneurial mindset or to enrich the content and strategy of entrepreneurship education.

\section{Conclusion}

The study aimed to determine the effect of entrepreneurial values and cognitive attitude of the ABM grade XII students and the fourth-year college students of business management course. The study found that overall the entrepreneurial values of students obtained a mean rating of 3.60 which is considered high except for autonomy orientation which is considered moderate. The same ratings were obtained for cognitive attitude toward the business and business behavioral intention. These findings conclude that the entrepreneurial values, cognitive attitude toward the business, and business behavioral intention of grade XII ABM and the fourth year college of business management course are high.

In terms of the difference between entrepreneurial values, cognitive attitude, and business behavioral intention of the ABM grade XII and the fourth-year college students of business management course is found to be no significant correlation. Therefore, the hypothesis is rejected. However, concerning the relationship between entrepreneurial values and business behavioral intention, cognitive attitude and business behavioral intention are to be found significantly correlated. Students with high entrepreneurial values manifest high business behavioral intention. Therefore, the hypothesis is accepted.

\section{References}

Abun, D., Foronda, S. L. G. L., Belandres, M. L. V., Agoot, F., \& Magallanes, T. (2018). Measuring Entrepreneurial Knowledge and Entrepreneurial Intention of ABM Grade XII, Senior High School Students of Divine Word Colleges in Region I, Philippines. EPH - International Journal of Educational Research, 2(3).

Abun, D., Foronda, S. L. G., Agoot, F., Belandres, M. L.V., \& Magallanes, T. (2018). Measuring entrepreneurial attitude and entrepreneurial intention of ABM grade XII, Senior High School Students of Divine Word Colleges in Region I, Philippines. International Journal of Applied Research, 4(4), 100-114.

Abun, D., Magallanes, Th., Encarnacion, M. J., Alkalde, F., \& Somera, K. A. (2019). Investigation of Cognitive and Affective Attitude of Students toward Environment and Their Environmental Behavioural Intention to Join Environmental Movement and Energy Conservation. The International Journal of Business Management and Technology, 3(6).

Ajzen, I. (1985). From intentions to actions: A theory of planned behavior. In J. Kuhl and J. Beckmann (Eds.), Action control: From cognition to behavior (pp. 11-39). New York: Springer-Verlag. https://doi.org/10.1007/978-3-642-69746-3_2

Ajzen, I. (1991). The theory of planned behavior. Organizational Behavior and Human Decision Processes, 50, 179-211. https://doi.org/10.1016/0749-5978(91)90020-T

Ajzen, I. (2001). Nature and Operation of Attitudes. Annual Review of Psychology, 52, 27-58. https://doi.org/10.1146/annurev.psych.52.1.27

Ajzen, I., \& Fishbein, M. (1975). Belief, attitude, intention, and behavior: An introduction to theory and research. Reading, MA: Addison- Wesley.

Ajzen, I., \& Fishbein, M. (1980). Understanding attitudes and predicting social behavior. Englewood Cliffs, NJ: Prentice-Hall.

Ariola, M. M. (2006). Principles and Methods of Research. Manila: National Bookstore.

Baah-Boateng, W. (2013). Human Capital Development: The Case of Education as a vehicle for Africa's Economic Transformation. Legon Journal of International Affairs and Diplomacy (LEJIAD), 7(1), 31-55.

Baht, A. (2020). Descriptive Research: Definition, Characteristics, Methods, Examples, and Advantages. Question Pro. Retrieved from https://www.questionpro.com.

Bandura, A. (1977). Self-efficacy: Toward a unifying theory of behavioral change. Psychological Review, 84, 191215. https://doi.org/10.1037/0033-295X.84.2.191

Bandura, A. (1986). Social foundations of thought and action: A social cognitive theory. Englewood Cliffs, NJ: Prentice-Hall.

Bandura, A. (1991). Self-efficacy mechanism in physiological activation and health-promoting behavior. In J. Madden (Ed.), Neurobiology of learning, emotion, and affect (pp. 229-269). New York: Raven. 
Bandura, A. (1994). Social cognitive theory and exercise of control over HIV infection. In R.J. DiClemente and J. L. Peterson (Eds.), Preventing AIDS: Theories and methods of behavioral interventions (pp. 25-29). New York: Plenum Press. https://doi.org/10.1007/978-1-4899-1193-3_3

Becker, M. H. (1974). The health belief model and personal health behavior. Health Education Monographs, 2, 324-508. https://doi.org/10.1177/109019817400200407

Becker, M. H. (1988). AIDS and behavior change. Public Health Reviews, 16, 1-11.

Best, J. R. (2010). Human Capital Development in Education: Challenges and Policy Option. Denver: McREL.

Bolton W. K., \& Thompson, J. L. (2000). Entrepreneurs: Talent, Temperament, Technique. Oxford: Butterworth Heinemann.

Broen, D., \& Assoiates (2002). Career Choice and Development (4 ${ }^{\text {th }}$ Ed.). New York: Jossey-Bass

Calman, K. C. (2004). Evolutionary ethics: can values change. Journal of Medical Ethics, 30, $366-370$. https://doi.org/10.1136/jme.2002.003582

Cambridge Dictionary. (n.d). Entrepreneur. Retrieved from https://dictionary.cambridge.org.

Cherry, K. (2020). Attitudes and Behaviors in Psychology. Very Well Mind. Retrieved from https://www.verywellmind.com.

Covin, J. G., Slevin, D.P. (1989). Strategic management of small firms in hostile and benign environments. Strategic Management Journal, 10(1), 75-87. https://doi.org/10.1002/smj.4250100107

Crocker, R. (2006). Human Capital Development and Education. Canada: CPRN

Desjardins, R. (2015). Education and Social Transformation. European Journal of Education, 50(3), $239-244$. https://doi.org/10.1111/ejed.12140

Dewey, J. (1922). Human Nature and Conduct. New York: Henry Holt and Company.

Dewey, J. (1938). Experience and education. New York: Macmillan.

Didar, A. F. (2020). Entrepreneurship, a Triangle of Values. Start-up Grind. Retrieved from https://www.startupgrind.com

Drucker, P. (1970). Entrepreneurship in Business Enterprise. Journal of Business Policy, 1(2).

Erkkilä, K. (2000). Entrepreneurial education: mapping the debates in the United States. Abingdon: Taylor \& Francis

Eroglu, A., \& Picak, M. (2011). Entrepreneurship, National Culture, and Turkey. International Journal of Business and Social Science, 2(16).

Fayolle, A., \& Gailly, B. (2008). From craft to science - Teaching models and learning processes in entrepreneurship education. Journal of European Industrial Training, 32, 569-593. https://doi.org/10.1108/03090590810899838

Feather, N.T. (1994). Values and national identification: Australian evidence. Australian Journal of Psychology, 46(1), 35-40. https://doi.org/10.1080/00049539408259467

Fishbein, M. (2000). The role of theory in HIV prevention. AIDS Care, 12(3), $273-278$. https://doi.org/10.1080/09540120050042918

Fishbein, M., \& Ajzen, I. (1975). Belief, attitude, intention, and behavior: An introduction to theory and research. Reading, MA: Addison-Wesley.

Fishbein, M., Middlestadt, S. E., \& Hitchcock, P. J. (1991). Using information to change sexually transmitted disease-related behaviors: An analysis based on the theory of reasoned action. In R. J. DiClemente \& J. L. Peterson (Eds.), Preventing AIDS: Theories and methods of behavioral interventions (pp. 61-78). (Reprinted in modified form from J. N. Wasserheit et al (Eds.). Research Issues in Human Behavior and Sexually Transmitted Diseases in the AIDS Era. Washington, DC: American Society for Microbiology, 1991, pp. 243266). Plenum Press. https://doi.org/10.1007/978-1-4899-1193-3_4

Fishbein, M., Triandis, H. C., Kanfer, F. H., Becker, M. H., Middlestadt, S. E., \& Eichler, A. (2001). Factors influencing behavior and behavior change. In A. Baum, T. R. Revenson, and J. E. Singer (Eds.). Handbook of health psychology (pp. 3-17). Mahwah, NJ: Lawrence Erlbaum

Gartner, W. B. (1990). What are we talking about when we talk about entrepreneurship? Journal of Business 
Venturing, 5, 15-28. https://doi.org/10.1016/0883-9026(90)90023-M

Gonsalez, J. A. M., \& Kobylinska, U. (2019). Influence of personal variables on entrepreneurial intention: A comparative study between Poland and Spain. Engineering Management in Production and Services, 11(1). https://doi.org/10.2478/emj-2019-0005

Halis, M., Ozsabuncuoglub, I. H., \& Ozsagir, A. (2007). The Values of Entrepreneurship and Factors that Effect entrepreneurship: Findings from Anatolia. Serbian Journal of Management, 2(1), 21-34.

Halstead, J. M., \& Taylor, M. J. (2000). The Development of Values, Attitudes, and Personal Qualities. Berkshire: National Foundation of Educational Research.

Haste, H. (2018). Attitudes and Values and the OECD Learning Framework 2030: A critical review of definitions, concepts, and data. Retrieved from https://www.oecd.org.pdf.

Hofstede, G. (1984). Culture's Consequences: International Differences in Work-Related Values. Thousand Oaks, CA: Sage Publications

Holwerda, J. (2018). The Relationship between Entrepreneurial Knowledge and Intention. Unpublished Thesis: Kajaanin Ammattikorkeakoulu University.

Investopedia. (n.d). Entrepreneur. Retrieved from https://www.investopedia.com

Investopedia. (n.d). Entrepreneurs and Entrepreneurship Defined. Retrieved from https://www.investopedia.com.

Jaen, I., Linan, F., \& Moriano, J. (2015). Beyond Entrepreneurial Intentions: Values and Motivations in Entrepreneurship. International Entrepreneurship and Management Journal, 10, 679-689. https://doi.org/10.1007/s11365-014-0306-7

Jaen, I., Linan, F., \& Moriano, J. (2015). Personal Values and Entrepreneurial Intention: An Empirical Study. A Conference Paper Presented at the ESU Conference, University of Tartu, Estonia.

Jovkovska, A., \& Barakoska, A. (2014). The Role of Education in the Formation of Values and Value Orientations among Adolescents. International Journal of Cognitive Research in Science, Engineering, and Education, 2(2).

Kadir, M. B. A., Salim, M., \& Kamarudin, H. (2012). The Relationship between Educational Support and Entrepreneurial Intentions in Malaysian Higher Learning Institution. Procedia - Social and Behavioral Sciences, 69, 2164-2173. https://doi.org/10.1016/j.sbspro.2012.12.182

Katz, D. (1960). The Function of Attitude. Public opinion quarterly, 24, 163-204. https://doi.org/10.1086/266945

Knight, F. H. (1921). Risk, Uncertainty, and Profit. Boston, MA: Hart, Schaffner \& Marx; Houghton Mifflin Company.

Koe, W. L., Krishnan, R., \& Utami, S. (2018). The Influence of Entrepreneurial Skills on Business Start-Up Intention Among Bumiputra Students. Journal of Advanced Manufacturing Technology, 12(2).

Koffka, K. (1935). Principles of Gestalt psychology. New York: Harcourt, Brace, and Company.

Lackeus, M. (2015). Entrepreneurship Education: Why, What, When, How. European Commission: OECD

Leedy, P. D. (1974). Practical Research: Planning and Design. New York: Macmillan.

Lin, L. L., Pena, A. V., \& Chen, C. N. (2017). Factors related to the Intention of Starting a New Business in El Salvador. Asia Pacific Management Review, 22(4). https://doi.org/10.1016/j.apmrv.2017.07.008

Mahieu, R. (2006). Agents of change and policies of scale: a policy study of entrepreneurship and enterprise in education. Doctoral thesis, Umeå Universitet

Malebana, M. J. (2014). The Effect of Knowledge of Entrepreneurial Support on Entrepreneurial Intention. Mediterranean Journal of Social Sciences, 5(20), 1020-1028. https://doi.org/10.5901/mjss.2014.v5n20p1020

Malovics, E., Farkas, G., \& Vajda, B. (2015). The appearance of Entrepreneurial Values and Strategic Orientation in the Basic Values. International Journal of Business and Management, 3(1), 18-35. https://doi.org/10.20472/BM.2015.3.1.002

Mankoff, A. W. (1974). Values-Nhatot Attitudes-Are the Real Key to Motivation. Management Review, 63, 23-29.

McClelland, D. C. (1961). The Achieving Society. New York: Van Nostrand. https://doi.org/10.1037/14359-000

McGrath, R. G., MacMillan I. C., Yang E. A., Tsai W. (1992). Does Culture Endure, or is it Malleable? Issues for Entrepreneurial Economic Development. J Bus Venturing, 7, 115-135. https://doi.org/10.1016/0883- 
9026(92)90019-N

McLeod, S. A. (2018). Attitudes and behavior. Simply Psychology. Retrieved from https://www.simplypsychology.org/attitudes.html

Meglino, B. M., Ravlin, E. C., \& Adkins, C. L. (1989). A Work Values Approach to Corporate Culture: A Field Test of Value Congruence Process and Its Relationship to Individual Outcomes. Journal of Applied Psychology, 74(3), 424-432. https://doi.org/10.1037/0021-9010.74.3.424

Morris, M., \& Schindehutte, M. (2005). Entrepreneurial Values and the Ethnic Enterprise: An Examination of Six Subcultures. Journal of Small Business and Management, 43(4). https://doi.org/10.1111/j.1540627X.2005.00147.x

National Research Council. (2003). Attitudes, Aptitudes, and Aspirations of American Youth: Implications for Military Recruitment. Washington, DC: The National Academies Press. https://doi.org/10.17226/10478.

OECD. (2019). Attitude and Values for 2030. Retrieved from http://www.oecd.org.pdf

Ortmeyer, D. (1949). The Concept of Attitude. Iowa: Iowa Academy of Science, Inc.

Ozarrali, N., \& Rivenburgh, N. (2016). Entrepreneurial Intention: Antecedence to Entrepreneurial Behavior in the USA and Turkey. Journal of Global Entrepreneurship Research, 6(3). https://doi.org/10.1186/s40497-0160047-x

QAA. (2012). Enterprise and entrepreneurship education: Guidance for UK higher education providers. Gloucester, UK: The Quality Assurance Agency for Higher Education.

Rokeach, M. (1973). The Nature of Human Values. New York: The Free.

Ronconi, L., \& Anchorena, J. (2012). Entrepreneurship, Entrepreneurial Values, and Public Policy in Argentina. Argentina: Inter-American Development Bank. https://doi.org/10.2139/ssrn.2156788

Rosenstock, I. M. (1974). The health belief model and preventive health behavior. Health Education Monographs, 2, 354-386. https://doi.org/10.1177/109019817400200405

Rozan, M. Z. A., \& Zibarzani, M. (2018). A study of entrepreneurial mindset through the dual-sided role as service seeker and service provider among university students. Pertanika Journal of Social Sciences and Humanities, 26(4), 2473-2487.

Sarasvathy, S. D. (2015). What Makes Entrepreneur Entrepreneurial? Retrieved from http://www.effectuation.org

Schumpeter, J. A. (1965). Economic Theory and Entrepreneurial History. In: Aitken HG (ed) Explorations in an enterprise. Cambridge, MA: Harvard University Press.

Schumpeter, J. A. (1980). A gazdasági Fejlődés elmélete. Budapest: KJK.

Semple, R. (2019). Do Values Change Over Time? Leadership Development. Retrieved from https://www.flashpointleadership.com

Shane, S., \& Venkataraman, S. (2007). The Promise of Entrepreneurship as a Field of Research \& Entrepreneurship. New York: Springer. https://doi.org/10.1007/3-540-48543-0_8

Smilor, R. (2004). The Values that Sustain Entrepreneur. Kauffman Entrepreneurs. Retrieved from https://www.entrepreneurship.org.

Smithers, D., \& Catanzaro, J.L. (2014). Innovate. Create. Execute. - An Entrepreneurial Mindset in Higher Education. Retrieved from https://www.tbr.edu/sites/tbr.edu/files/Dayna\%20Smithers.pdf

Statistic Solutions (n.d). Multiple Regression. Retrieved from https://www.statisticssolutions.com

The World Bank (2020). Countries can Take Steps Now to Rebuilt from Covid-19. Retrieved from https://www.worldbank.org

The World Bank. (2020). Global Economic Prospect. Retrieved from https://www.worldbank.org

Titchener, E. B. (1910). A Text-Book of Psychology. New York: The MacMillan Company. https://doi.org/10.1037/11606-000

Triandis H.C. (1972). The analysis of subjective culture. New York: John Wiley and Sons.

Türkkahraman, M. (2014). Social values and value of education. Procedia - Social and Behavioral Sciences, 116, 633-638. https://doi.org/10.1016/j.sbspro.2014.01.270

UPSTATE University of South Carolina. (n.d). Literature Review: Purpose of a Literature Review. Library. 
Retrieved from https://uscupstate.libguides.com

Wasserheit, J., Aral, S., \& Holmes, K. (Eds.) (1991). Research issues in human behavior and sexually transmitted diseases in the AIDS era (pp. 243-257). Washington, DC: American Society for Microbiology

Weber, M. (1905). The Protestant Ethic and the Spirit of Capitalism. New York, United States: Unwin Hyman.

Whatls.com (n.d). Empirical Analysis. Retrieved from https://whatis.techtarget.com

Williams, M.K. (2017). John Dewey in the $21^{\text {st }}$ Century. Journal of Inquiry \& Action in Education, 9(1).

Јоксимовић, С., \& Јањетовић, Д. (2008). Појам о себи и вредноснеоријентаиијеадолеси ената, Зборник Института за педагошка истраживања. Београд, 2, 288-305.

\section{Copyrights}

Copyright for this article is retained by the author(s), with first publication rights granted to the journal.

This is an open-access article distributed under the terms and conditions of the Creative Commons Attribution license (http://creativecommons.org/licenses/by/4.0/). 